\title{
Managing Economic Security of Metallurgical Enterprises under the Conditions of Transformation Changes in the Economy
}

\author{
MARYNA IVANOVA ${ }^{1}$, SVITLANA TIUTCHENKO ${ }^{2}$, OLENA GROSHELEVA ${ }^{3}$, TETIANA FONAROVA ${ }^{4}$, \\ EDUARD RYZHKOV ${ }^{5}$ \\ ${ }^{1}$ Department of Management, DNIPRO UNIVERSITY OF TECHNOLOGY, UKRAINE. \\ E-mail: ma riva@ukr.net \\ ${ }^{2}$ Department of Economic and Information Security, DNIPRO STATE UNIVERSITY OF INTERNAL AFFAIRS, \\ UKRAINE \\ ${ }^{3}$ Department of Management, DNIPRO UNIVERSITY OF TECHNOLOGY, UKRAINE \\ ${ }^{4}$ Department of Management, DNIPRO NATIONAL METALLURGICAL ACADEMY OF UKRAINE, UKRAINE \\ ${ }^{5}$ Department of Economic and Information Security, DNIPRO STATE UNIVERSITY OF INTERNAL AFFAIRS, \\ UKRAINE.
}

\begin{abstract}
The article proposes a method for assessing the level of economic security of metallurgical enterprises by the "pyramid of economic security". It is based on priority components of economic security, selected for the enterprises under studies, such as the capability of resistance, risk reduction and economic succession, and established indicators of their causal relationships with exogenous and endogenous factors of influence. The assessment results allow differentiating the levels of the enterprise economic security; the practical application of the "pyramid of economic security" will provide a more realistic assessment of the enterprise's economic security for prompt and effective response to urgent threats and possible risks. The authors have developed a model for assessing the effectiveness of economic security management in enterprises by the rate of changes in the enterprise economic succession; the model is based on the indicators of resource and impact decoupling, financial, social and eco-decoupling.
\end{abstract}

Keywords: economic security, risk, transformational change, competitiveness, modeling

JEL Classification: C51, 011, 012 


\section{Introduction.}

Today, the strategic goal of transformational changes in the economy is the formation of competitive industrial enterprises as equal partners in the world economic community, or clustered as a separate form of operation according to M. Ivanova [3]. The implementation of these requirements, as evidenced by world experience, is possible on the basis of consistent application of the tools of economic security management in enterprises, which should be based on an assessment of their capability to adapt in the changing space of functioning according to R. Miśkiewicz and R. Wolniak [11]. The issue of ensuring the economic security of industrial enterprises is currently relevant and is drawing the attention of researchers to various theoretical, methodological and practical aspects.

The vast majority of methodological tools for assessing the enterprise economic security are based on models that use deterministic causality and causal unidirectional relationships. However, the use of these models has shown their inadequacy for assessing the enterprise economic security in the context of transformational changes in the economy and has led to significant deviations from reality, which causes difficulties making prompt decisions to prevent risks and threats. All this requires further study of existing problems in assessing the level of the enterprise economic security and finding ways to solve them [6].

A detailed study of the existing methodological toolkit for assessing the enterprise economic security has shown that today, a toolkit for integral assessment based on one or another group of priority criteria and, consequently, on diverse approaches, is becoming increasingly widespread. We consider it expedient to conditionally divide these approaches into:

1) $P$-approaches (those that have become most common in foreign and domestic practice): resource, cyclical, systemic, target, process, situational, financial, and investment approaches;

2) $\mathrm{N}$-approaches (the newest approaches, which are becoming more widespread with transformational changes in the economy): digital, beneficial, stakeholder, and reputational approach.

We consider it expedient to supplement the list of $\mathrm{N}$-approaches to assessing the enterprise economic security with an environmental approach, that is, an assessment of the economic security in terms of environmental, economic and social threats.

To assess the level of economic security of metallurgical enterprises using the "pyramid of economic security", the authors propose a three-component index for assessing their economic security, which is determined by formula (1):

$$
\mathrm{EES}=f(\mathrm{Pc} ; \mathrm{Pp} ; \mathrm{Ec})
$$

where EES is an integral assessment of the level of the enterprise economic security;

$P c$ is an integral index of resistance;

$\mathrm{Pp}$ is an integral index of risk reduction;

Ec is an integral index of economic succession.

This model is based on the assessment of the rate of changes in the economic succession of enterprises, i.e. their capability to develop environmentally assessed by the decoupling approach. Unlike the existing methods, this one is based on the resource and impact financial, social and ecodecoupling indicators and involves determining the economic succession indicator as a triune metric. O. Vatchenko et al. [14] considers the achievement of the decoupling effect to be one of the most important tasks for the metallurgical enterprises that are moving towards sustainable development and building a "green" economy. This minimizes the negative effects of economic growth, such as depletion of resources and social consequences of anthropogenic pressure on the environment.

We consider the most clear and comprehensive interpretation of the concept of "decoupling" to be an eco-economic approach, where attention is mainly focused on the environmental component of economic growth, which is primarily associated with the human impact on the environment and the conservation of natural resources. 


\section{Review of empirical literature.}

The issues of economic security have been studied in the works of many scientists. Thus, L. Mikhnevych [8] analyzed the links between the country's image and the level of its economic security. For this purpose, the author identified scientific clusters for the investigation of economic security and stated the need to take into account not only the quantitative economic parameters of the country, but also the political factors. S. Vasylishyn [13] identified the factors of economic security in the context of the social component and found out that the mechanism for managing the economic security of enterprises is the interaction and interrelation of its components: assessment, analysis, management and control of metrics that reflect the enterprise performance through its productivity and efficiency. M. Lysenko [7] also studied the factors that affect the safety of the enterprise, the environmental component being the major among them in the author's opinion.

S. Ivanov [2] addressed his research to the use of decoupling metrics that assess the relation between environmental pollution, resource use and economic growth. He revealed the relationship between economic growth, different types of environmental pollution and the use of natural resources in a particular region, and justified measures to reduce the negative impact of industry on the environment.

In general, according to the level of development of economic security systems in enterprises and the quality of scientific and methodological support of these systems, we can distinguish three geographical centers: 1) the United States and Canada; 2) Great Britain; 3) Australia and New Zealand. These countries were among the first to introduce requirements to ensure the economic security of companies at the legislative level, and introduced appropriate standards. Such control and regulation procedures have provided additional, in addition to market, incentives to form and maintain the economic security system of an enterprise at the appropriate level and prevent bankruptcy. The topic is relevant given the relationship between economic security of the state, national security and economic security at the micro, meso and macro levels (enterprises, region and country). A. Kleffner et al. [5] analyzed the performance of three companies: Aerotech, Electroworks, Wealthfund, and proposed a mechanism for limiting risks and their impact on economic security.

The problem of ensuring economic security requires additional methodological tools for its assessment. According to Ye. Mishchuk [10], assessment of economic security according to the stakeholder approach should be based on estimating a missing amount of unspent expenditures, which is calculated as a difference between the threshold amount that must (should) have been incurred to satisfy the economic interests of stakeholders and the actual amount of expenditures incurred. It should be noted that an advantage of the stakeholder approach to assessing the level of the enterprise economic security is that it allows comparing the level of economic security before and after the implementation of strategic measures, such as M\&A operations.

J. Rayner [12], G. Honey (2009), B. Kisil [4] emphasize that in the integral assessment of the enterprise economic security, it is advisable to use reputational risk matrices, which link the probability of a risk situation with the impact on reputation or possible losses which will be borne by the enterprise when the situation occurs. In particular, J. Rayner [12] proposes to use a risk matrix that links risks to the level of financial losses (including the restoration of stakeholder confidence).

There is a great diversity of approaches to assessing the enterprise economic security, but, as practice shows, the multi-criteria assessment complicates their application in practice, and therefore there is a need to define criteria that would simplify the procedure for assessing economic security and provide prompt decision-making on curbing possible threats and risks. 


\section{Data and specific model.}

\subsection{The Data: Source and Description.}

According to the proposed method for assessing the enterprise economic security by the "pyramid of economic security", one of the components of the triple indicator EES (Pc; Pp; Ec) is economic succession. The article proposes to assess the economic succession by integral indices finan-, socialand eco-decoupling through generalizing the indicators resource and impact DecouplingFactor (as a fundamental basis for achieving the goals of sustainable development), determined from the chained growth rate of indicators of endogenous and exogenous factors of influence.

Achieving the decoupling is one of the most important tasks for metallurgical enterprises that are moving towards the sustainable development and are in the process of transforming to the environmental economy.

According to O. Vatchenko et al. [14], decoupling minimizes the negative effects of economic growth, such as depletion of resources and social consequences of anthropogenic pressure on the environment, i.e. an increase in human incidence of diseases associated with environmentally destructive economic development.

Therefore, considering economic succession as the capability of the enterprise to environmental development, which involves a simultaneous combination of economic, social and environmental components, we find it necessary to determine this index by a three-component indicator of decoupling, which should combine indicators of financial, social and eco-decoupling.

\subsection{Presentation of the Model.}

According to V. Vitlinsky [15], the decoupling effect is manifested when, with a positive dynamics of economic growth, indicators of negative impact on the environment remain stable or show a downward trend over the same period. According to O. Vatchenko et al. [14], eco-economic decoupling is decoupling of environmental pressures from economic growth and it is observed in the case of increasing production while reducing the negative impact on the environment from any economic activity, i.e. increasing eco-efficiency. Resource decoupling refers to reducing the rate of resource use per unit of economic result and is due to increasing resource productivity.

V. Malashchenko [8] characterizes decoupling via the following indicators:

-resource decoupling - decoupling by the natural resource intensity of production (the rate of using natural resources per unit of economic activity);

-impact decoupling - decoupling by environmental load of production (the level of the negative impact of production on the environment).

The authors improved the approach proposed by O. Vatchenko et al. [14] for evaluating the components of decoupling.

\subsubsection{The Decoupling factor in terms of anthropogenic pressure.}

The calculation of the decoupling factor according to anthropogenic pressure on the environment is carried out according to the formula:

$$
\text { Decoupling Factor=1- Decoupling Index }
$$

$$
\text { Decoupling Index }=\frac{E P_{E}}{D F_{E}} / \frac{E P_{B}}{D F_{B}}=\frac{E P_{E}}{E P_{B}} / \frac{D F_{E}}{D F_{B}}=\frac{I_{E P}}{I_{D F}}
$$

where DFE, DFB (Driving Force) is an indicator of economic growth of EBITDA in E-year (End is for the final year of measurements) and $B$-year (Basic is for the beginning of measurements);

$E P_{E}, E P_{B}$ (Environment Pressure) are indicators of anthropogenic pressure; 
$I_{E P}$ is growth rate, or index of relative change in anthropogenic pressure on the environment in the end period compared to the base period, \%;

$I_{D F}$ is growth rate of economic growth indicator, expressed in terms of physical volume index EBITDA, \%.

In this case, the Decoupling Index reflects the percentage change in the rate of growth or decrease in anthropogenic pressure on the environment in the event of a change in EBITDA by $1 \%$ over a period of time.

\subsubsection{Resource Decoupling factor.}

Resource Decoupling factor is calculated by the formula:

Decoupling Factor=1- Decoupling Index,

$$
\text { Decoupling Index }=\frac{N_{E}}{D F_{E}} / \frac{N_{B}}{D F_{B}}=\frac{N_{E}}{N_{B}} / \frac{D F_{E}}{D F_{B}}=\frac{I_{N}}{I_{D F}}
$$

where $N_{E}, N_{B}$ is the amount of resource consumed in the final and base (start of measurements) periods, natural units;

$I_{N}$ is growth rate, or index of the physical volume of the consumed resource.

In this case, the Decoupling index is understood in a similar way, but in terms of resource consumption.

\subsubsection{Generalized integral indices of eco-decoupling.}

Generalized integral indices of decoupling in terms of environmental pressure $\left(F_{1}\right)$ and resource consumption $\left(E_{1}\right)$ are calculated using the geometric mean of the growth rates of all types of pollution or resources consumed in a given year:

$$
\begin{aligned}
& \mathrm{F}=1-\left(\sqrt[b]{\frac{E P_{E 1}}{E P_{B !}} \times \frac{E P_{E 2}}{E P_{B 2}}} \times \ldots \frac{E P_{E m}}{E P_{B m}} / \frac{D F_{E}}{D F_{B}}\right)=1\left(\sqrt[m]{I_{E P 1}} \times I_{E P 2} \times \ldots \times I_{E P m} / I_{D F}\right) \\
& \mathrm{F}=1-\left(\sqrt[m]{\frac{N_{E 1}}{N_{B !}} \times \frac{N_{E 2}}{N_{B 2}}} \times \ldots \frac{N_{E n}}{N_{E n}} / \frac{D F_{E}}{D F_{B}}\right)=1-\left(\sqrt[m]{I_{N 1}} \times I_{N 2} \times \ldots \times I_{N m} / I_{D F}\right),
\end{aligned}
$$

where $m$ is the number of factors of anthropogenic pressure, i.e. types of pollution;

$n$ is the number of types of consumed natural resources;

$1,2, \ldots, m$ are specific types of anthropogenic pressure on the environment;

$1,2, \ldots, n$ are types of natural resources.

The results of the Decoupling factor calculations are interpreted as follows:

1) Decoupling Factor $>0$ and increases in dynamics: the effect of decoupling is observed, i.e. there is a decrease in anthropogenic pressure on the environment or saving of a certain type of resources, while EBITDA is increasing;

2) Decoupling Factor $<0$ and decreases in dynamics: economic growth leads to a significant increase in anthropogenic pressure or depletion of certain types of resources;

3) Decoupling Factor $=0$ : indicates the equal rates of economic growth and anthropogenic pressure or consumption of certain types of resources.

Integral DecIndex $Y_{\text {PInti }}$ based on the generally accepted method of calculating the Decoupling Index is determined by the formula: 


$$
\text { DecIndex } Y_{P I n t i}=\frac{K_{P I n t i}}{K_{E}}
$$

\subsection{FinanDecoupling.}

Indicators of impact and resource finanDecoupling are evaluated as follows:

- impact finanDecoupling: by comparing the dynamics of the growth rate of total debt $T D_{E} \%$ to the chained growth rate of $E B I T D A, E B_{E}, \%$;

- resource finanDecoupling: by comparing the dynamics of the growth rate of capital investment $C I_{E}, \%$ to the chained growth rate of EBITDA, EBE, \%:

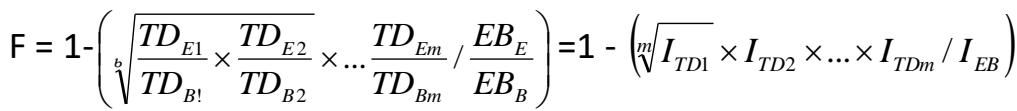

$$
\begin{aligned}
& \mathrm{E}=1-\left(\sqrt[m]{\frac{C I_{E 1}}{C I_{B !}} \times \frac{C I_{E 2}}{C I_{B 2}}} \times \ldots \frac{C I_{E n}}{C I_{E n}} / \frac{E B_{E}}{E B_{B}}\right)=1-\left(\sqrt[m]{I_{C I 1}} \times I_{C I 2} \times \ldots \times I_{C I m} / I_{E B}\right)
\end{aligned}
$$

where $T D$ (total debt) is the total debt of the enterprise;

$E B$ is for EBITDA, Earnings before Interest, Taxes, Depreciation, and Amortization;

$\mathrm{Cl}$ (Capital Investment) is capital investment of the enterprise, aimed at modernizing the production process.

\section{4 socialDecoupling.}

To calculate the impact and resource socialDecoupling indicators, it is recommended to use aggregate financial statements of enterprises. In this case, the impact socialDecoupling (formula 11) is found by comparing the dynamics of the increase in the number of accidents with disability $A_{E} \%$ to the chained growth rate of EBITDA, EBE, \%; resource socialDecoupling (formula 12) is obtained by comparing the dynamics of the increase in the number of employees $N E_{E,} \%$ to the chained growth rate of EBITDA, $E B_{E}, \%$ :

$$
\begin{gathered}
\mathrm{F}=1-\left(\sqrt[b]{\frac{A_{E 1}}{A_{B !}} \times \frac{A_{E 2}}{A_{B 2}}} \times \ldots \frac{A_{E m}}{A_{B m}} / \frac{E B_{E}}{E B_{B}}\right)=1-\left(\sqrt[m]{I_{A 1}} \times I_{A 2} \times \ldots \times I_{A m} / I_{E B}\right) \\
\mathrm{E}=1-\left(\sqrt[m]{\frac{N E_{E 1}}{N E_{B !}} \times \frac{N E_{E 2}}{N E_{B 2}}} \times \ldots \frac{N E_{E n}}{N E_{E n}} / \frac{E B_{E}}{E B_{B}}\right)=1\left(\sqrt[m]{I_{N E 1}} \times I_{N E 2} \times \ldots \times I_{N E m} / I_{E B}\right),
\end{gathered}
$$

where $A$ (accidents) is the number of accidents with disability;

$N E$ is the number of employees;

$E B$ is for EBITDA, Earnings before Interest, Taxes, Depreciation, and Amortization;

$\mathrm{TI}$ (Investment) - investment in occupational safety and health.

\subsection{Economic succession.}

The indicator of economic succession Ec should be evaluated by generalized indicators resource and impact DecouplingFactor, calculated based on the chained growth rate of endogenous and exogenous factors of influence:

$$
\mathrm{Ec}=f(F d ; S d ; E d),
$$


where $F d$ is an integral index of financial decoupling;

$S d$ is an integral index of social decoupling;

$E d$ is an integral index of environmental decoupling;

The proposed three-component index for assessing the level of economic succession in metallurgical enterprises is advised to evaluate by the level of compliance of its components with the boundary value selected as unit. If a component deviates from the selected boundary value as a result of economic activity, this component should be conditionally equated to 0 .

In the case of environmental development, the $E c$ indicator will take the form:

$$
\text { Ec }(1 ; 1 ; 1)
$$

Given the above, the value of the EES is considered sufficient if the actual value of the components (Pc; Pp; Ec) is equal to their boundary (sufficient) value:

$$
\mathrm{EES}=f(1 ; 1 ; 1)
$$

If the actual value of the indicators (Pc; Pp; Ec) is equal to zero, then the value of the EES indicator is considered hazardous:

$$
\mathrm{EES}=f(0 ; 0 ; 0)
$$

The indicator of the enterprise economic security differentiates eight different levels which conditionally correspond to four safety zones.

The zone of absolute safety includes enterprises characterized by the capability to resist exogenous and endogenous factors, the capability to minimize or avoid existing risks and threats to the business and whose activities are accompanied by environmental development.

Enterprises in the pre-crisis (critical) zone are characterized primarily by economic instability and financial dependence.

The crisis zone includes enterprises that are characterized by economic instability and financial dependence, as well as non-compliance with standards of corporate social responsibility or environmental protection.

Enterprises whose recovery is not possible even after remediation measures belong to the hazardous zone.

The assignment of an enterprise to a particular zone of economic security will be correct with a high-quality assessment of threats and proper information support.

\section{Estimation, findings and analysis.}

\subsection{Calculation of finanDecoupling.}

The data of aggregate financial statements of enterprises are the basis for determining the indicators of finanDecoupling (Table 1).

Thus, the integral index DecIndexY $Y_{\text {Inti }}$ is the ratio of the chained growth rate of the integrated impact of financial indicators $T D_{E}, \%$ to the chained growth rate of EBITDA, $E B_{E}, \%$.

Based on the generally accepted method of calculating the Decoupling Factor, the integral DecFactor $Y_{\text {PInti }}$ should be determined by formula (2).

However, for a more in-depth and actual research and enabling to predict DecFactor ${ }_{\text {PInti }}$ or DecFactor $_{1}$, we believe it appropriate to expand the list of influencing factors with consolidated revenues $T K B$, and the volume of iron $T V_{1}$ and steel $T V_{2}$ production. 
Table 1. Input data for an assessment of impact and resource finanDecoupling metrics of a metallurgical enterprise

\begin{tabular}{|c|c|c|c|c|c|c|c|c|c|}
\hline \multirow{2}{*}{ Indicators } & \multicolumn{9}{|c|}{ Years } \\
\hline & 2011 & 2012 & 2013 & 2014 & 2015 & 2016 & 2017 & 2018 & 2019 \\
\hline \multicolumn{10}{|c|}{ Financial indicators, million USD } \\
\hline EBITDA & 2552 & 3655 & 1985 & 2361 & 2702 & 525 & 1153 & 2044 & 2513 \\
\hline$T D$ (total debt) & 2036 & 2945 & 3734 & 4308 & 3232 & 2946 & 2969 & 3017 & 2743 \\
\hline $\begin{array}{l}\text { Cl (Capital } \\
\text { Investment) }\end{array}$ & 582 & 1165 & 765 & 747 & 613 & 285 & 374 & 542 & 898 \\
\hline \multicolumn{10}{|c|}{ Chained growth rates of financial indicators, $\%$} \\
\hline EBITDA & 7.63 & 43.22 & -45.69 & 18.94 & 14.44 & -80.57 & 19.62 & 77.28 & 22.95 \\
\hline$T D$ (total debt) & 53.43 & 44.65 & 26.79 & 15.37 & -24.98 & -8.85 & 0.78 & 1.62 & -9.08 \\
\hline $\begin{array}{l}\text { Cl (Capital } \\
\text { Investment) }\end{array}$ & 16.62 & 100.17 & -34.33 & -2.35 & -17.94 & -53.51 & 31.23 & 44.92 & 65.68 \\
\hline DeclndexY PInti & 18.40 & 72.41 & -3.77 & 6.51 & -21.46 & -31.18 & 16.00 & 23.27 & 28.30 \\
\hline
\end{tabular}

The multiple nonlinear dependence of DecFactor ${ }_{1}$ on the above factors of influence will then take the form:

$$
\text { DecFactor }_{1}=f\left(T K B, T V_{1} ; T V_{2}\right)
$$

The coefficients of multiple nonlinear regressions DecFactor ${ }_{1}$ evaluated by the results of correlation-regression analysis after their initial linearization using the generalized least squares method allowed to estimate the dependence of DecFactor ${ }_{1}$ on changes in the above factors in a matrix form:

$$
\text { DecFactor }_{1}=0.402+\left(0.042 * T V_{1}\right)^{3}+0.071 * T V_{2}+(0.012 * T K B)^{3}
$$

Analysis by Chaddock scale and Fisher criterion proves that the proposed mathematical model is adequate to the statistical data and can serve as a basis for an economic analysis.

\subsection{Calculation of socialDecoupling.}

The next component of assessing the level of economic succession by the decoupling approach is socialDecoupling, which is determined similarly to finanDecoupling through the indicators resource and impact DecouplingFactor, and the integral index DecouplingFactor ${ }_{2}$. Input data and calculated indicators are presented in Table 2.

Based on the data presented in Table 2, the impact socialDecoupling was analyzed according to the changing growth rate of the total number of accidents with disability $A_{E}, \%$ and the growth rate of EBITDA $E B_{E}, \%$. The indicator resource SocialDecoupling is estimated by comparing the dynamics of the growth rate of the number of employees $N E_{E}, \%$ to the chained growth rate of EBITDA EBE, \%. The integral index DecIndexY PInti is a comparison of the chained growth rate of the integral impact of social responsibility indicators to the chained growth rate of EBITDA $E B_{E} \%$.

However, for more realistic forecasting of DecFactor ${ }_{\text {PInti }}$ Or DecFactor $_{2}$, we consider it appropriate to expand the list of influencing factors, supplementing it with investment in occupational safety and health $T I_{2}$ and volumes of production of iron $T V_{1}$ and steel $T V_{2}$.

Hence, the multiple nonlinear dependence of DecFactor $_{2}$ on the above factors of influence will take the form:

$$
\text { DecFactor }_{2}=f\left(T I_{2}, T V_{1} ; T V_{2}\right)
$$


Table 2. Dynamics of indicators of corporate social responsibility of the metallurgical enterprise

\begin{tabular}{|c|c|c|c|c|c|c|c|c|c|}
\hline \multirow[b]{2}{*}{ Indicators } & \multicolumn{9}{|c|}{ Years } \\
\hline & 검 & 궁 & $\stackrel{m}{\stackrel{n}{0}}$ & 呄 & $\stackrel{n}{\stackrel{n}{0}}$ & $\begin{array}{l}0 \\
\stackrel{1}{0}\end{array}$ & 공 & $\stackrel{\infty}{\stackrel{\infty}{0}}$ & 궁 \\
\hline \multicolumn{10}{|c|}{ Indicators of corporate social responsibility, million USD } \\
\hline TI (Investment) & $\begin{array}{l}\infty \\
\text { ñ } \\
\text { గొ }\end{array}$ & $\begin{array}{l}\infty \\
\stackrel{0}{0} \\
\stackrel{-}{0}\end{array}$ & $\begin{array}{l}\infty \\
\dot{J} \\
\stackrel{్}{\circ}\end{array}$ & 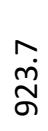 & $\begin{array}{l}\infty \\
\stackrel{+}{m} \\
\underset{H}{-}\end{array}$ & $\begin{array}{l}\stackrel{-}{+} \\
\stackrel{\infty}{-} \\
\stackrel{-}{-}\end{array}$ & 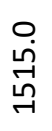 & $\underset{\stackrel{N}{N}}{\stackrel{N}{N}}$ & 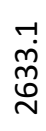 \\
\hline NE (number of employees) & 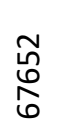 & $\begin{array}{l}\stackrel{N}{N} \\
\stackrel{N}{N} \\
\stackrel{్}{0}\end{array}$ & $\begin{array}{l}\text { ○ } \\
\infty \\
\infty \\
\infty\end{array}$ & $\begin{array}{l}\text { 동 } \\
\text { ᄋे }\end{array}$ & 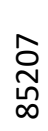 & $\begin{array}{l}\text { 우 } \\
\text { ஜి } \\
\text { هి }\end{array}$ & $\begin{array}{l}\stackrel{\infty}{\sim} \\
\text { N్} \\
\infty\end{array}$ & $\begin{array}{l}\infty \\
\stackrel{\infty}{0} \\
\mathscr{ర}\end{array}$ & 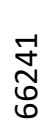 \\
\hline A (accidents) & 오 & $\stackrel{\hat{n}}{\sim}$ & $\underset{\sim}{\forall}$ & $\underset{r}{\stackrel{P}{+}}$ & $\underset{\sim}{\sim}$ & $\underset{\sim}{\stackrel{\infty}{\sim}}$ & 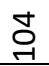 & ஜே & $\stackrel{\infty}{\sim}$ \\
\hline \multicolumn{10}{|c|}{ Chained growth rates of corporate social responsibility indicators, $\%$} \\
\hline A (accidents) & $\underset{\text { Nָ}}{\stackrel{\text { }}{N}}$ & $\begin{array}{l}\text { ન્- } \\
\text { ને }\end{array}$ & $\begin{array}{l}\text { O } \\
\infty \\
\text { p. }\end{array}$ & $\begin{array}{l}\tilde{\varphi} \\
\dot{+} \\
\overrightarrow{+}\end{array}$ & $\begin{array}{l}\vec{N} \\
\stackrel{+}{\circ} \\
\stackrel{+}{1}\end{array}$ & $\stackrel{\substack{+\sim}}{ }$ & $\begin{array}{l}\stackrel{n}{N} \\
\stackrel{\infty}{\rightarrow} \\
\rightarrow\end{array}$ & †ُ & $\begin{array}{l}\stackrel{n}{\Upsilon} \\
\infty \\
\stackrel{\infty}{\rightarrow}\end{array}$ \\
\hline NE (number of employees) & $\underset{1}{\hat{T}}$ & $\begin{array}{l}\text { ठ } \\
\text { ñ }\end{array}$ & 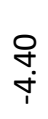 & $\begin{array}{l}\underset{-}{-} \\
\infty \\
\infty\end{array}$ & $\underset{n}{n}$ & 농 & ڤִ & $\underset{\sim}{\stackrel{0}{N}}$ & $\stackrel{\vec{m}}{0}$ \\
\hline DeclndexY $Y_{\text {Inti }}$ & 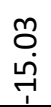 & 今े & 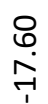 & $\underset{m}{\stackrel{n}{-}}$ & $\begin{array}{l}\text { ம் } \\
\infty \\
1\end{array}$ & $\underset{\forall}{\approx}$ & $\begin{array}{l}\stackrel{9}{\sim} \\
\stackrel{-}{\sim} \\
\stackrel{1}{1}\end{array}$ & $\begin{array}{l}\stackrel{m}{\rightarrow} \\
\stackrel{\sim}{\sim} \\
\stackrel{+}{+}\end{array}$ & $\begin{array}{l}\text { N̦ } \\
\text { क् }\end{array}$ \\
\hline
\end{tabular}
form:

The dependence of DecFactor $_{2}$ on changes in the above factors has been estimated in a matrix

$$
\text { DecFactor }_{2}=1.394+2.170 * T V_{1}^{-1}+0.071 * T V_{2}^{1 / 9}+\left(0.018 * T I_{2}\right)^{3}
$$

According to the Chaddock scale and Fisher criterion, we can assume that the proposed mathematical model is adequate to the statistical data and on the basis of the adopted model it is possible to estimate the economic succession.

\subsection{Calculation of EcoDecoupling.}

One of the components of the three-component indicator of economic succession is the indicator ecoDecoupling. When evaluating the impact ecoDecoupling indicators, we consider it expedient to use the indicators of the three most important factors, whose values are given in Table 3.

The impact ecoDecoupling indicator is calculated by comparing the growth rate dynamics of the integral impact of production on the environment $K_{P I 3}(\%)$ to the chain-linked growth rate of EBITDA $K_{E}(\%)$.

The resource ecoDecoupling indicator is calculated by comparing the growth rate dynamics of direct energy use $K_{P K 3}(\%)$ to the chain-linked growth rate of EBITDA $K_{E}(\%)$.

The integral index DecIndexY $Y_{\text {IInti }}$ is the ratio of the chained growth rate of the environmental indicators $K_{P I n t 3}(\%)$ to the chained growth rate of EBITDA $K_{E}(\%)$.

For more in-depth research and realistic forecasting of DecFactor ${ }_{\text {PInti }}$ or DecFactor 3 , we consider it appropriate to expand the list of influencing factors with investment in environmental protection $\mathrm{TI}_{3}$ and the volumes of iron $T V_{1}$ and steel $T V_{2}$ production. Hence, the multiple nonlinear dependence of DecFactor $_{3}$ on the above factors of influence will take the form:

$$
\text { DecFactor }_{3}=f\left(T I_{3}, T V_{1} ; T V_{2}\right)
$$


Table 3. Dynamics of indicators of a metallurgical enterprise pressure on the environment

\begin{tabular}{|c|c|c|c|c|c|c|c|c|c|}
\hline \multirow{2}{*}{ Indicators } & \multicolumn{9}{|c|}{ Years } \\
\hline & 2011 & 2012 & 2013 & 2014 & 2015 & 2016 & 2017 & 2018 & 2019 \\
\hline $\begin{array}{l}T I \quad \text { Investment in } \\
\text { environmental protection, } \\
\text { million USD }\end{array}$ & 481.3 & 444.3 & 446.5 & 269.6 & 177.5 & 194 & 179 & 225 & 263 \\
\hline $\begin{array}{l}P_{I 3_{-} 1} \text { Gross greenhouse } \\
\text { gas emissions in } \mathrm{CO}_{2} \\
\text { equivalent, million tons }\end{array}$ & 26.4 & 25.7 & 22.4 & 17.3 & 12.9 & 9.8 & 10.8 & 8.9 & 9.8 \\
\hline $\begin{array}{l}P_{I 3 \_2} \text { Total wastewater } \\
\text { discharge, million } \mathrm{m}^{3}\end{array}$ & 876 & 952 & 860 & 721 & 649 & 594.3 & 580.8 & 594.9 & 605.1 \\
\hline $\begin{array}{l}P_{I 3_{-} 3} \text { Volume of waste } \\
\text { generation, million tons }\end{array}$ & 237.2 & 160.4 & 137.1 & 179.2 & 167.0 & 192.4 & 178.7 & 213.7 & 220.2 \\
\hline \multicolumn{10}{|c|}{ Chained growth rates of environmental pressure, $\%$} \\
\hline $\begin{array}{l}K_{P I 3} \text { Integral index of } \\
\text { environmental pollution }\end{array}$ & 24.15 & -8.78 & -12.34 & -2.74 & -14.08 & -5.75 & 0.27 & 1.47 & 4.96 \\
\hline$K_{P K 3}$ Direct energy use & -2.67 & 68.53 & -29.69 & -22.25 & -21.94 & 358.98 & 4.50 & 12.09 & 3.16 \\
\hline $\begin{array}{l}\text { DeclndexYPInti Integral } \\
\text { index }\end{array}$ & 10.74 & 29.87 & -21.02 & -12.49 & -18.01 & 176.62 & 2.39 & 6.78 & 4.06 \\
\hline
\end{tabular}

To estimate the impact ecoDecoupling, we first find a generalized integral index of environmental pressure according to the following formula:

$$
P_{I 3}=\frac{P_{I 3 \_1}+P_{I 3 \_2}+P_{I 3 \_3}}{3}
$$

After carrying out the analysis, data smoothing and comparison of different models, the authors propose a dependence of the following type:

$$
\text { DecFactor }_{3}=1.419+4.464 * T V_{1}^{-1}+0.313 * T V_{2}^{-1}+\left(0.009 * T I_{3}\right)^{3}
$$

According to the criteria for estimating the parameters, it can be argued that the proposed mathematical model is adequate and, if adopted, can serve as a basis for economic analysis.

\subsection{Assessment of economic succession of metallurgical enterprises using the decoupling approach.}

Based on the results of correlation and regression analysis of enterprise reporting data and given the exogenous factors of influence, multiple nonlinear dependences of managing the economic succession of metallurgical enterprises were established. After the initial linearization of the dependences by the generalized least squares method in matrix form, the following relationships were revealed (Table 4).

Table 4. Economic and mathematical models for estimating the economic succession of metallurgical enterprises

\begin{tabular}{c|c}
\multicolumn{1}{c}{ by the decoupling approach } & F-test \\
\hline Decoupling & 1.956 \\
DecFactor social $=1.394+2.170 * T V_{1}^{-1}+0.071 * T V_{2}^{1 / 9}+\left(0.018 * T I_{2}\right)^{3}$ & 2.876 \\
DecFactor eco $=1.419+4.464 * T V_{1}^{-1}+0.313 * T V_{2}^{-1}+\left(0.009 * T I_{3}\right)^{3}$ & 2.210 \\
\hline
\end{tabular}

It has been found that for all the models of DecouplingFactor there is a $75 \%$ reliability that the proposed mathematical models are adequate to the statistical data and should be introduced for assessing the level of economic security of enterprises in terms of economic succession. 
For the forecast values of the consolidated revenue $K B=20196$ million USD as well as the volumes of production of pig iron $V_{1}=10256.25$ thousand tons and steel $V_{2}=9153.75$ thousand tons, the forecast value of the decoupling factor was found as: DecouplingFactor $1=3.92$.

For the forecast values of investment in occupational safety and health $I_{2}=4476.27$ million USD, and the volumes of pig iron production $V_{1}=10256.25$ thousand tons and steel production $V_{2}=9153.75$ thousand tons, the forecast value of the decoupling factor was found as: DecouplingFactor $2=$ 3.74.

For the forecast values of investment in occupational safety and health $I_{3}=394.5$ million USD, the volumes of production of pig iron $V_{1}=10256.25$ thousand tons and steel $V_{2}=915.75$ thousand tons, the forecast value of the decoupling factor was found as: DecouplingFactor $3=1.85$.

It has been stated that as of the end of 2019, the level of the enterprise economic security, estimated as the score via the indicators of resistance $P_{c}(0)$, risk reduction $P_{P}(1)$ and economic succession Ec (1), is characterized by a three-component index of economic security $\operatorname{EES}(0 ; 1 ; 1)$.

Based on the matrix of economic security zones for enterprises according to the three-component index EES, the level of the enterprise economic security is currently characterized as pre-critical, though manageable, where timely response to challenges and threats can protect the enterprise against risks and losses.

Thus, the study has validated the hypothesis that the economic security of metallurgical enterprises under the conditions of constant transformational changes in the economy is recognized as the sustainability of enterprises to challenges and threats, and their capability to environmental development.

\section{Conclusions.}

The study has been inspired by the need to develop methods for assessing the economic security of enterprises in the face of constant transformational changes in the economy. With broadening the understanding of the enterprise economic security, approaches to its estimation need to be rethought. The authors have formed a definition of economic security by the merological approach as a clearly structured system of providing resistance, risk reduction and economic succession of enterprises under the conditions of uncertainty and changeability of their operation environment. Economic succession is defined as the capability of enterprises to environmental development and, unlike the existing models, is based on indicators of resource and impact finance, social and eco-decoupling, which allows estimating the index of economic succession as a threefold indicator.

The study has developed a system of criteria for assessing the enterprise economic security by a deterministic approach. Practical application of the criteria will allow the metallurgical enterprises to form an eventual development strategy in the medium and long term and effectively manage the impact of destabilizing factors. With a stable system of criteria for assessing the economic security of enterprises, entities should focus their efforts on creating and maintaining their own security systems.

\section{References}

1. Honey, G. (2009). A Short Guide to Reputation Risk. Farnham: Gower Publishing, 131.

2. Ivanov, S.V., O.B. Vatchenko, K.O. Svystun, B.S. Vatchenko, and O.V. Oskoma (2019). Analysis of decoupling of economic growth, environmental pressure and resource use in Dnipropetrovsk region. Naukovyi Visnyk Natsionalnoho Hirnychoho Universytetu, 6. 169-175. URL://doi.org/10.29202/nvngu/2019-6/25/.

3. Ivanova, M.I., Faizova, S.O., Boichenko, M.V., Balalaiev, O.K. and Smiesova, V.L. (2020). Clustering as a tool for managing industrial enterprise. Naukovyi Visnyk Natsionalnoho Hirnychoho Universytetu, 3. 96-102. URL://doi.org/10.33271/nvngu/2020-3/096. 
4. Kisil', B.O. (2016). Methods of identification and evaluation of reputational risks of an enterprise. Molodyj vchenyj, 12.1 (40). 782-786.

5. Kleffner, A.E., Lee, R.B. and McGannon, B. (2003). The Effect of Corporate Governance on the Use of Enterprise Risk Management: Evidence From Canada. Risk Management and Insurance Review, $6,53-73$.

6. Kwilinski, A. and Kuzior, A. (2020). Cognitive Technologies in the Management and Formation of Directions of the Priority Development of Industrial Enterprises. Management Systems in Production Engineering, 28(2), 133-138. https://doi.org/10.2478/mspe-2020-0020

7. Lysenko, M. (2014). The Problem of Ensuring the Economic Security of Dairy Industry in Ukraine. Economics \& Sociology, 7(2),160-171.

8. Malaschenko, V. (2011). Economic security of the enterprise as a factor of effective corporate governance. Visnyk Natsional'noi akademii derzhavnoho upravlinnia pry Prezydentovi Ukrainy, 3. 283-291.

9. Mikhnevych, L., Marchenko, V., Hristov, P. and Kuzior, A. (2020). Conceptual Relationships Between Country Image and Economic Security. Marketing and Management of Innovations, 1, 285-293.

10.Mischuk, Ye.V. (2020). Valuation of the state of economic security of mining enterprises (on the example of property security). Innovatsijna ekonomika, 1-2 (82), 166-179.

11.Miśkiewicz, R. and Wolniak, R. (2020). Practical Application of the Industry 4.0 Concept in a Steel Company. Sustainability, 12(14), 5776. https://doi.org/10.3390/su12145776

12.Rayner, J. (2003). Managing reputational risk: curbing threats, leveraging opportunities. Chichester; Hoboken, N.J.: Wiley, 131.

13.Vasylishyn, S. and Yarova, V. (2020). Analytical Provision Of Socio-Economic Security Management At Macro And Microlevels. Estudios de Economia Aplikada, 38-3(1).

URL://ojs.ual.es/ojs/index.php/eea/article/view/3965.

14.Vatchenko, O.B. and Svystun, K.O. (2019). Decoupling in economics - essence, definitions and types. Ekonomichnyj prostir, 141, 5-24.

15.Vitlins'kyj, V.V. and Velykoivanenko, H.I. (2004). Riscology in economics and entrepreneurship. Kyiv: KNEU, 480. 